\title{
Application of Chromatographic and Infra-Red Spectroscopic Techniques for Detection of Adulteration in Food Lipids: A Review
}

\author{
J. M. N. Marikkar, M.E.S. Mirghani and I. Jaswir \\ International Institute for Halal Research and Training, International Islamic University Malaysia, Malaysia
}

\author{
"Correspondence to: \\ J. M. Nazrim Marikkar \\ International Institute for Halal Research and \\ Training, International Islamic University \\ Malaysia, P.O. Box 10, 50728 \\ Kuala Lumpur, Malaysia \\ Tel: +60-3-6196 5619, Fax: +60-3-6196 5596 \\ E-mail: nazrim@iium.edu.my
}

Received: November 18, 2015

Accepted: February 11, 2016

Published: February 14, 2016

Citation: Marikkar JNM, Mirghani MES, Jaswir I. 2016. Application of Chromatographic and Infra-Red Spectroscopic Techniques for Detection of Adulteration in Food Lipids: A Review. J Food Chem Nanotechnol 2(1): 32-41.

Copyright: (C) 2016 Marikkar et al. This is an Open Access article distributed under the terms of the Creative Commons Attribution 4.0 International License (CC-BY) (http://creativecommons. org/licenses/by/4.0/) which permits commercial use, including reproduction, adaptation, and distribution of the article provided the original author and source are credited.

Published by United Scientific Group

\begin{abstract}
Adulteration of oils and fats is an important commercial issue, which needs intervention from regulatory agencies. Tremendous amount of research has been carried out during the past several decades to address this, starting from classical methods to more sophisticated instrumental techniques. Instrumental techniques based on chromatography and infrared spectroscopy have received particular attention from researchers worldwide since they are fast and efficient. Majority of the past studies suggested the use of assays based on fatty acids, triacylglycerol components, minor constituents, and spectral characteristics as they are really useful to determine the adulteration of food lipids. A discussion on the specificity and sensitivity of these assays in solving adulteration issues of oils and fats is timely. Hence, the purpose of this review is to present an update of the current literature in this topic and provide some directions for future research.
\end{abstract}

\section{Keywords}

Analysis of fats, Food adulteration, FTIR, GLC, HPLC, Lipids

\section{Introduction}

Food authentication has become an important aspect of food quality control. As there are numerous practices of fraudulent nature in the food sector [1], it has become highly essential to establish procedures to monitor food quality at various stages of production, processing and distribution. Fat and oil processing industry is no exception to fraudulent practices. There are many reported cases of adulteration practices for highly priced vegetable oils and fats such as virgin olive oil, cocoa butter etc. [1-4]. As extra virgin olive oil is a premium-product, which is short in supply and high in demand, there has always been temptations for its adulteration with cheaper oils [5] or other sub-branded olive products such refined olive oil and olive pomace oil [6]. This tendency has ultimately prompted many European olive-growing countries to impose high tariffs on cottonseed oil imports and adopt a common legislation to protect olive producers and consumers [7]. In recent times, coconut oil industry has shown lack of competitiveness with other major vegetable oils due to its ever-increasing cost of production. Palm olein on the other hand, is a much cheaper product to be imported for blending purposes and hence, coconut oil adulterated with palm olein are sold as 'genuine' product in many Asian countries.

Animal body fats such as lard, beef and mutton tallow could find some applications in the food sector. They are cheap to be used as substitutes since voluminous amounts of animal fats are generated by the carcass industry [8]. Lard, for instance, was a major source of shortening in North America and other 
Western European countries for a long time. Apart from its use as a component in food applications, deliberate mixing of lard in vegetable oils, fats and dairy products could be possible due to economic reasons [9-12]. Since lard and palm oil have some similarities with respect to chemical composition and physical characteristics [13], it could be mixed easily with palm oil. Seriburi \& Akoh [14] demonstrated that mixing of lard with sunflower oil in different ratios could produce a variety of plastic shortenings. Lard has often been a potential substitute for dairy products like ghee [15] and butter [16] since it showed good compatibility to these products. However, mixing of animal fats with plant oils may not be desirable due to religious restrictions and negative nutritional perception regarding the consumption of animal fats. Hence, a great deal of research has gone into development of methods to authenticate food against the adulteration of animal fats.

Studies on food authentication issues have been conducted for the past several decades. As there has been a huge influx of information on food authenticity, many attempts were made time to time to present reviews on this area. As early as nineteen eighties, Rossell and co-workers [4] summarized different classical approaches for detection of adulterations in oils and fats. Rossell [17] also discussed the criteria for determining the purity of selected edible vegetable oils using both classical and modern instrumental approaches. As adulteration of virgin olive oil has always been an issue of increasing importance, there were several attempts to update the developments in the detection of adulterations in virgin olive oil $[18,19]$. In the recent past, Reid and co-workers [20] presented a general overview on the applications of spectroscopic (mid infrared, near infrared, Raman spect), chromatographic (gas liquid chromatography and high performance liquid chromatography), and thermo analytical techniques (differential scanning calorimetry) on determining the authenticity of various kinds of foods. As the technological advancement in food authentication takes place at a faster rate, there is still a need for an updated review of the current literature with a specific focus on the quality assurance of oils and fats. Hence, this article is intended to present a review of the studies carried out on the applications of chromatographic and infra-red spectroscopic techniques on detection of adulteration in vegetable oils and fats.

\section{Different Analytical Approaches}

Fatty acid analyses

Sseveral scientific investigations were carried out in the past to develop analytical methodologies based on fatty acid (FA) compositional data to detect and quantify adulterations in fats and oils [Table 1]. Fatty acid analysis by gas liquid chromatography (GLC) system equipped with a polar capillary column and flame ionization detector (FID) was useful to establish the purity of oils and fats. More recent work on oil authenticity has concentrated on the compilation of FA composition for various oils and fats. The Codex Committee on Fats and Oils which was established by the joint FAO/ WHO Codex Alimentarious Commission published FA composition ranges for typical commercial samples of bona fide fats and oils. However, it was recognized that these ranges were not definitive and hence, it had to undergo revision from time to time. This was due to the fact that FA compositional changes were possible based on varietal differences, differences in geographical origins, and the influence of seed maturity [21]. For the detection of adulteration, the relative abundance of individual FA in a given sample is needed to be crosschecked with a reference FA data base. When the determined FA values of a sample deviates significantly from the range found in the reference, it could be suspected to have undergone adulteration. This approach has been useful to detect groundnut oil contamination with soybean oil [17], detection of either vegetable oils or animal body fats in ghee [22], as well as animal fat adulterations in palm kernel oil [8]. Selection of a marker fatty acid is an important step to detect adulterations in oils and fats. For instance, lauric acid was the marker to detect coconut oil adulteration in soybean oil, cottonseed oil and tallow as it did not occur in significant proportions in these oils. Occurrence of castor oil contamination in some vegetable oils was ascertained by means of ricinoleic or hydroxystearic acid content [23]. In another instance, 11, 14-eicosadienoic acid (C20:2) was the marker to detect lard adulteration in beef and mutton fat [12] though later investigations proved that the use of 11, 14-eicosadienoic acid (C20:2) as sole indicator to detect lard would not be reliable [24].

Generally, getting a positive indication of adulteration would become difficult, if the FA compositions of the contaminant and the original oil were closely similar. Most of the time, this remained as a challenge in several adulteration cases. In such instances, alternative strategies such as fractional crystallization of lipids, regio-specific analysis of FA using pancreatic lipolysis, FA ratio calculations and principle component analysis (PCA) of FA data have been adopted by investigators $[7,25]$. When extra-virgin olive oil was adulterated either by refined olive oil or olive pomace oil, detection of adulteration especially at lower levels $(<5 \%)$ became quite difficult by mere comparison of the overall fatty acid data [26]. Detection of adulteration of olive oil with other seed oils (cottonseed, sesame, corn, and soybean) [23] and detection of lard in butter fat (ghee) were resolved using fractional crystallization [27]. Gamazo-Vazquez and co-workers [28] proposed to take oleic and linoleic acid ratio as the diagnosis parameter since detection of olive oil adulteration by other seed oils below 5 (\%) became practically difficult. Interestingly, this approach enabled the detection of contamination of olive oil with sunflower oil at the lowest of $1 \%$ level. Similarly, Seo and co-workers [29] suggested to the use of stearic acid content in combination with the ratio between linoleic and oleic acid to detect sesame oil adulteration by corn oil. This method, however, could detect sesame oil adulteration only above 5\% level. For detection of milk fat adulteration with foreign fats such as lard, tallow and palm oil, FA ratios C14:0/C18:2 and C18:2/C18:0 were used as parameters. For successful discrimination between pure milk fat and admixtures containing more than $3 \%$ lard could be achieved by the application of linear-discrimination analysis to FA data [22]. In another case, Dourtoglou and co-workers [7] applied PCA to the total and region-specific FA data to discriminate pure olive oil from those adulterated 
with corn, soybean, sunflower and cottonseed oils. According to this study, even samples adulterated at $5 \%$ level could be discriminated along with the possibility of knowing the type of the adulterant.

As lard is reported to have some unique pattern of FA substitution in its TAG structure, looking into positional distribution of FA within the glycerol backbone of the suspected lipid sample would be a more reliable approach to detect lard in food systems. This was tested to detect vegetable oil contamination with lard [25], to trace products, which were deep-fried in lard [30], as well as meat products contaminated with pork [11]. As lard in comparison to any other animal fat or plant oil would possess excessive amounts of palmitic acid in its $s n-2$ position [31], the percentage of palmitic acid content at the $s n-2$ position of lipids extracted from product contaminated with lard would also be high. The validity of this approach was even tested to differentiate genuine olive oil from those which were modified. According to Firestone and co-workers [6], determination of the percent palmitic and stearic acids at the $s n-2$ position of TAG molecules was helpful to distinguish genuine olive oil from esterified olive oil samples. However, this approach is laborious and timeconsuming since it involves several steps to achieve the results.

Investigations were also carried out find biomarkers from isomeric forms of unsaturated fatty acids to detect adulterations. On several occasions, conventional GC systems coupled with FID did not have the capacity to resolve isomeric forms of unsaturated fatty acids. Hence, efforts were diverted to employ advanced version of GLC systems. While GLC hyphenated with mass spectrometer was found to give greater details of FA composition [32], comprehensive two-dimensional gas chromatography (GCxGC) was able to unravel the entire spectrum of individual components, including those which occur in lower abundance or in different isomeric forms [33]. According to some recent reports, these advanced forms of GC systems were able to distinguish lard from other animal fats $[34,35]$. As these preliminary studies have been mainly focused on distinguishing lard from other animal fats, further investigation would be necessary to show their potential applications in detecting lard in complex lipid mixtures.

\section{Triacylglycerol compositional analyses}

TAG compositional analyses have been extensively explored as means of detection of adulterations in oils and fats [Table 1] [36]. The use of packed column GC to determine TAG compositions of lipid products helped to detect adulterations in milk fat [37] and cocoa butter [38]. In both of these, high temperature short columns were employed to develop equations incorporating the major TAG peaks to discriminate pure samples (milk fat and cocoa butter) from the adulterated ones. As these equations were meant to define pure milk fat, their use helped to detect non-milk fat adulterants present in milk products at 5\% level with $99 \%$ confidence [37]. As genuine $\mathrm{CB}$ is comprised of only three major TAG species namely, POP, POS and SOS, a straight line relationship was found between $\mathrm{C}_{50}$ and $\mathrm{C}_{54}$ contents based on the natural variability of POP, POS and SOS [38]. According to this method, the minimum detection limit of cocoa butter equivalents in chocolate fat was $15 \%$ at $95 \%$ confidence limit [38]. Quantitatively, this method also helped to estimate the amount of cocoa butter equivalents in suspected samples of chocolate fat. TAG compositional analyses using GC fitted with high temperature columns were also employed to detect lard in food systems [39]. As lard was found to have six dominant TAG $\left(\mathrm{C}_{46}, \mathrm{C}_{48}, \mathrm{C}_{50}, \mathrm{C}_{52}, \mathrm{C}_{54}\right.$, and $\left.\mathrm{C}_{56}\right)$ with $\mathrm{C}_{52}$ being the major TAG $[39,40], \mathrm{C}_{52} / \mathrm{C}_{38}$ ratio was found to be a sensitive index for detection of lard in butter fat [38]. After analyzing TAG composition of four different Canadian butter fats (ranging in iodine value from 34.8 to 39.1), Parodi [40] found that the lower limit of detection for lard in butterfat was 5 to $10 \%$.

With modernization, packed column GC system was largely replaced by high-temperature capillary column GC system due to rapidity in providing TAG profiles. The improved system was successful in detecting non-milk fat component in goat milk fat [41] as well as lard in ewe's milk fat [42]. Fontecha and co-workers [41] employed a fairly high number of goat milk samples from five different herds of goats to develop a formula to define pure goat milk fat in terms of TAG composition. The formula was found to be useful to indicate deviations of goat milk due to 3 to $5 \%$ adulterations either by palm oil or tallow. According to Goudjil and coworkers [42], use of capillary column GC system would be able to detect lard adulterations exceeding 5\% in ewe's milk fat based on the multiple linear regression equations obtained using the TAG composition of pure ewe's milk fat and its adulterated blends [Table 1] [42]. In another study, Simoneau and co-workers [43] employed capillary GC column to detect plant based cocoa butter equivalents $(\mathrm{CBE})$ in $\mathrm{CB}$. As TAG compositions of CBEs and $\mathrm{CB}$ were not identical, the differences between them was useful to detect the presence of the CBEs in confectionery products $[43,44]$. In this method, plots of percentages of specific TAG of CB would help to identify deviations due to adulteration practices. As various plant fats exhibited different deviating values from those of $\mathrm{CB}$, several plots were needed to provide optimal detection and quantification level [43].

Analysis of TAG composition by reversed-phase (RP) HPLC for detection of adulteration in oils and fats has seen another phase of development. The use of RP-HPLC in the detection of oil adulteration gained much attention due to ease of sample preparation as well as the natural variations in fatty acid composition do not affect the characteristic TAG profile of several oils and fats [45]. This approach was particularly useful for detection of adulteration of virgin olive oil with various seed oils rich in linoleic acid [45] as well as vegetable oils mixed with lard [33]. In majority of the cases, vegetable oil adulterations with animal fats are generally found to cause some deviations mainly on the existing TAG molecular species of the TAG elusion profiles [36]. Adulteration of palm kernel oil with animal fats such as lard and beef tallow, however, was tend to cause additional TAG peaks visible even at adulteration level as low as 5\% [36]. Kapoulas and Andrikopoulos [45] introduced a HPLC-method which enabled the detection of low levels of seed oils such as sunflower, soybean, cottonseed and corn oils as adulterants in olive oil. According to this 
Table 1: A summary overview of chromatographic methods used for detection of adulterations in food lipids.

\begin{tabular}{|c|c|c|c|c|}
\hline Product & Objective to detect & Analytical technique & Main results & Ref. no. \\
\hline $\begin{array}{l}\text { Meat lipids of } \\
\text { fresh meat species and } \\
\text { canned meat products }\end{array}$ & Lard in meat lipids & $\begin{array}{l}\text { GLC coupled with FID detector to } \\
\text { determine overall fatty acid data }\end{array}$ & $\begin{array}{l}\text { Presence of } 11,14 \text {-eicosadienoic acid }(\mathrm{C} 20: 2) \text { indicated } \\
\text { pork in meat products. Minimum detection was } 1 \%(\mathrm{w} / \mathrm{w})\end{array}$ & {$[12]$} \\
\hline $\begin{array}{l}\text { Milk lipids of cow and } \\
\text { buffalo ghees }\end{array}$ & Lard in milk lipids & $\begin{array}{l}\text { GLC coupled with FID detector to } \\
\text { determine overall fatty acid data }\end{array}$ & $\begin{array}{l}\text { Deviations in behenic (C22:0), oleic (C18:1), stearic } \\
\text { (C18:0) and palmitic (C16:0) helped for detection. } \\
\text { Minimum detection was 5\% (w/w) }\end{array}$ & {$[27]$} \\
\hline $\begin{array}{l}\text { Milk lipids of cow and } \\
\text { buffalo ghees }\end{array}$ & Lard in milk lipids & $\begin{array}{l}\text { GLC coupled with FID detector to } \\
\text { determine component unsaponifiable matter }\end{array}$ & $\begin{array}{l}\text { Deviation in } n \text {-nonacosane concentration helped for } \\
\text { detection. Minimum detection was } 5 \%(w / w) \text {. }\end{array}$ & {$[15]$} \\
\hline $\begin{array}{l}\text { Lipids of fried peanut, } \\
\text { tempeh, chicken and beef }\end{array}$ & Fried oils contaminated with lard & $\begin{array}{l}\text { GLC coupled with FID detector to } \\
\text { determine fatty acid data of the } s n-2 \text { position }\end{array}$ & $\begin{array}{l}\text { High value for palmitic acid enrichment factor was } \\
\text { indicator of lard }\end{array}$ & {$[30]$} \\
\hline Milk fat of cow and ewe & Non milk fat mixed with milk fat & $\begin{array}{l}\text { GLC coupled with FID detector to } \\
\text { determine overall fatty acid data }\end{array}$ & $\begin{array}{l}\text { C14:0/C18:2 and C18:2/C18:0 were sensitive } \\
\text { parameters. Minimum detection 10\% (w/w) }\end{array}$ & {$[22]$} \\
\hline Milk fat of cow and ewe & $\begin{array}{l}\text { Lard and palm oil in milk fats } \\
\text { of cow and ewe }\end{array}$ & $\begin{array}{l}\text { GC fitted with high-temperature } \\
\text { capillary column to determine }\end{array}$ & $\begin{array}{l}\text { The deviation in } \mathrm{M} \text { value of the model } \sum \text { ai } C i=M+e \\
\text { using values of } \mathrm{C} 42, \mathrm{C} 44, \mathrm{C} 48, \mathrm{C} 50 \text {, and } \mathrm{C} 52 \text { indicated } \\
\text { adulteration. Minimum detection was } 5 \%(\mathrm{w} / \mathrm{w})\end{array}$ & {$[42]$} \\
\hline Milk fat of goat & $\begin{array}{l}\text { Palm oil and tallow mixed in } \\
\text { goat milk fat }\end{array}$ & GC fitted with short capillary column & $\begin{array}{l}\text { The deviation in M value of the model } \sum \text { ai } C i=M+e \\
\text { using values of } \mathrm{C} 42, \mathrm{C} 44, \mathrm{C} 48, \mathrm{C} 50 \text {, and } \mathrm{C} 52 \text { indicated } \\
\text { adulteration. Minimum detection was } 5 \%(\mathrm{w} / \mathrm{w})\end{array}$ & {$[41]$} \\
\hline Cocoa butter & Plant fats in cocoa butter & $\begin{array}{l}\text { High resolution GC fitted with } \\
\text { high-temperature capillary column }\end{array}$ & $\begin{array}{l}\text { Quantification of added cocoa butter equivalence could } \\
\text { be achieved down to a } 5 \%(\mathrm{w} / \mathrm{w}) \text {. The identification of } \\
\text { the nature of the foreign fat added was also possible. }\end{array}$ & {$[43]$} \\
\hline Milk lipids of butter & Non-milk fat adulterants in milk & Packed column $\mathrm{GC}$ to determine $\mathrm{C}_{52}$ content & Minimum detection limit of $5 \%(w / w)$ was achieved & {$[39,40]$} \\
\hline Milk lipids & $\begin{array}{l}\text { Non-milk fat mixed with } \\
\text { milk fat }\end{array}$ & $\begin{array}{l}\text { Packed column GC to determine TAG } \\
\text { compositions }\end{array}$ & Minimum detection limit of $5 \%(\mathrm{w} / \mathrm{w})$ was achieved & {$[37]$} \\
\hline Cocoa butter & $\begin{array}{l}\text { Cocoa butter equivalents in } \\
\text { chocolate fat }\end{array}$ & $\begin{array}{l}\text { Packed column GC to determine TAG } \\
\text { compositions }\end{array}$ & Minimum detection limit of $15 \%(\mathrm{w} / \mathrm{w})$ was achieved & {$[38]$} \\
\hline $\begin{array}{l}\text { Vegetable oils of palm, } \\
\text { Palm kernel, and canola }\end{array}$ & $\begin{array}{l}\text { Vegetable oils adulterated } \\
\text { with lard }\end{array}$ & $\begin{array}{l}\text { GLC coupled with FID detector to } \\
\text { determine fatty acid data of the } s n-2 \text { position }\end{array}$ & $\begin{array}{l}\text { CANDISC analysis of fatty acid data of the } s n-2 \text { position } \\
\text { helped to discriminate oils contaminated with lard }\end{array}$ & {$[25]$} \\
\hline $\begin{array}{l}\text { Meat lipids of } \\
\text { fresh meat species and } \\
\text { canned meat products }\end{array}$ & Lard in meat lipids & $\begin{array}{l}\text { HPLC coupled with RI detector to } \\
\text { TAG profiling of samples }\end{array}$ & $\begin{array}{l}\text { Significant increase in SSU/SUS ratio when pork was } \\
\text { added } 1 \%(\mathrm{w} / \mathrm{w}) \text { into beef and } 3 \%(\mathrm{w} / \mathrm{w}) \text { into mutton. }\end{array}$ & {$[11]$} \\
\hline $\begin{array}{l}\text { Vegetable oils of palm, } \\
\text { Palm kernel, and canola }\end{array}$ & $\begin{array}{l}\text { Vegetable oils adulterated } \\
\text { with lard }\end{array}$ & $\begin{array}{l}\text { TAG profiling of the lipids of } \\
\text { different vegetable oils using HPLC } \\
\text { couples with RI detector }\end{array}$ & $\begin{array}{l}\text { CANDISC analysis of TAG compositional data helped } \\
\text { to discriminate oils contaminated with lard }\end{array}$ & {$[36]$} \\
\hline Virgin olive oil & $\begin{array}{l}\text { Linoleic rich seed oils in virgin } \\
\text { olive oil }\end{array}$ & $\begin{array}{l}\text { HPLC coupled with RI detector to } \\
\text { TAG profiling of samples }\end{array}$ & $\begin{array}{l}\text { Tri-linoleoylglycerol (LLL) TAG peak was identified as } \\
\text { a good biomarker to detect olive oil adulteration }\end{array}$ & {$[45,46]$} \\
\hline $\begin{array}{l}\text { Lipids of fried peanut, } \\
\text { tempeh, chicken and beef }\end{array}$ & Fried oils mixed with lard & $\begin{array}{l}\text { HPLC coupled with RI detector to } \\
\text { TAG profiling }\end{array}$ & $\begin{array}{l}\text { The characteristic TAG profiling provided direct } \\
\text { evidence for lard contamination in these products }\end{array}$ & {$[30]$} \\
\hline Olive oil & Hazel nut oil in olive oil & $\begin{array}{l}\text { Reversed-phase liquid chromatography } \\
\text { coupled to gas chromatography }\end{array}$ & $\begin{array}{l}\text { (E)-5-methylhept-2-en-4-one was found to be a } \\
\text { potential biomarker for the rapid recognition of olive } \\
\text { oils adulterated with hazelnut oils }\end{array}$ & {$[53]$} \\
\hline Olive oil and butter & $\begin{array}{l}\text { Milk fat mixed with palm oil / } \\
\text { olive oil mixed with sunflower oil }\end{array}$ & $\begin{array}{l}\text { GLC coupled with FID detector to } \\
\text { determine sterol compositional data }\end{array}$ & $\begin{array}{l}\text { Possible to detect the presence of sunflower oil in olive } \\
\text { oil or of palm oil in milk fat, down to as low as } 5 \%(w / w)\end{array}$ & {$[54]$} \\
\hline Olive oil & $\begin{array}{l}\text { Olive oil adulteration by other } \\
\text { seed oils }\end{array}$ & $\begin{array}{l}\text { GLC analysis of sterols using polar } \\
\text { capillary column }\end{array}$ & $\begin{array}{l}\text { An olive oil authenticity factor based on the summation of } \\
\text { campesterol and stigmasterol percentages was established } \\
\text { as an indicator of olive oil adulteration with vegetable oils. } \\
\text { The minimum detection limit was } 5 \%(\mathrm{w} / \mathrm{w}) \text {. }\end{array}$ & {$[55]$} \\
\hline Extra virgin olive oil & $\begin{array}{l}\text { Adulteration of extra virgin } \\
\text { olive oil with other seed oils }\end{array}$ & RP-HPLC with florescence detector & $\begin{array}{l}\text { The ratio of } a-/(b+c) \text {-tocopherol concentrationas a first } \\
\text { screening marker of the authenticity of extra vergin } \\
\text { olive oil was established. }\end{array}$ & {$[65]$} \\
\hline Dark chocolate & $\begin{array}{l}\text { Palm mid-fraction in dark } \\
\text { chocolate }\end{array}$ & HPLC system with florescence detector & $\begin{array}{l}\text { a-tocotrienol was a potential biomarker to detect palm } \\
\text { mid fraction in cocoa butter. Minimum detection limit } \\
\text { was } 5 \%(w / w)\end{array}$ & {$[68,69]$} \\
\hline
\end{tabular}

Abbreviations: CANDISC, canonical discrimination; MAG, monoacylglycerol, TAG, triacylglycerol; RI, refractive index.

method, olive oil adulteration was detected using trilinoleoylglycerol (LLL) TAG peak as marker since it was a TAG almost absent in several olive oil samples. The validity of this approach was later tested by Antoniosi and co-workers [46] who used soybean oil as the potential adulterant in olive oil. The detection limit of this method was as low as $4 \%$.

On several occasions, HPLC detection of adulteration in olive oils became more difficult when the TAG composition of the adulterant was almost similar to that of main oil [47]. As canola oil is also characterized by high content of monounsaturated TAG, which was within the limits of olive oil, detection of canola oil in olive oil would become more difficult [47]. A similar situation was encountered in the case of olive oil adulteration with high-oleic sunflower oil. In such cases, alternative strategies were adopted to resolve the adulteration issues. Use of multivariate data analysis techniques such as PCA became inevitable to find solutions. 
Application of PCA to TAG compositional data obtained by reversed-phase HPLC offer was found to be an effective way to discriminate pure olive oil from those adulterated with maize, rapeseed, cottonseed, sunflower, and soybean oils. It was possible to discriminate authentic olive oil samples from oil samples adulterated at $10 \%$ level and above $[48,49]$.

Use of multivariate statistical approaches was also investigated for detection of lard in common vegetable oil such as palm oil, palm kernel oil, and canola. When discriminant analysis was performed to liquid chromatographic data of the adulterated samples, it was possible to discriminate vegetable oil samples adulterated with lard [36]. On another instance, plotting a graph using the linear relationship between LOO/ $\mathrm{LOP}$ and OOO/POO ratios as variables was found to be one of the effective methods of authentication of virgin olive oil from other sub-branded olive oils [49]. This became possible using a database of TAG compositions of various grades of commercial olive oils coming from major olive producing countries [49]. In this approach, deviations in genuine products could be pinpointed easily as lack of adherence to this line would mean that a sample was defective in some manner.

\section{Minor component analyses}

Most vegetable oils and fats are generally found to contain some minor components as unsaponifiable matter. These minor components could be sterols, triterpene alcohols, or hydrocarbons such as n-eicosane, $n$-docosane, squalene, carrotinoids, etc [50]. Cholesterol is present as the minor component in majority of the animal body fats as well as milk fats [51]. Although researchers in the past have shown much interest to study minor components of oils and fat due to nutritional significance [52], their determination has helped for detection of adulterations. Sterol analysis, for instance, has been used for detection of vegetable fats in milk fat, margarine in butter, various seed oils in olive oil [53], and animal fats in vegetable fats [54]. Recently, Azadmard-Damirchi [18] presented a review on the use of phytosterols in the detection of olive oil adulteration with hazelnut oil, or other sub-branded olive products.

According to conventional methods of analysis, the unsaponifiable matter of lipids is extracted and analyzed directly using GC systems as total sterols. This approach has greatly helped to handle adulteration of olive oil with other seed oils such as corn, sunflower, soybean and cottonseed oils. The usefulness of sterols analysis by GLC has been demonstrated to detect olive oil adulteration by other seed oils using thermo stable polar columns [55]. In majority of olive oils, campesterol, stigmasterol, $\beta$-sitosterol and $\Delta 5$-avenasterol were found as major sterols that account for more than $95 \%$ of total sterols present. Interestingly, the relative proportions of these four sterols were found to be fitting into an equation as given below (Eq 1). The Af value of the majority of olive oil samples were in the range 19.7-25.45 with an average of 21.99 \pm 1.65 , while those of corn, sunflower, soybean and cottonseed oils were in the range 2.04-2.9. Hence, the addition of 5\% of corn, sunflower, soybean and cottonseed oils tended to decrease the Af value of olive oil to 9.9, 13.5, 12.5 and 13.7. This kind of deviations in test samples may indicate possible adulteration in olive oil. However, this method might not be applicable to detect hazelnut and lampante oils since the relatively proportions of campesterol and stigmasterol in these two oils were extremely lower.

Af $=[100-($ Campesterol $\%+$ stigmasterol $\%)] /$ (Campesterol\% + stigmasterol\%)

Alternatively, sterol fraction may be isolated into individual component by using either thin layer chromatography or chromatography on a silica gel column and subsequently analyzed using GC either as free sterols or trimethylsilyl derivatives. For better accuracy, determination of free and esterified sterols in oils and fats can be done using either capillary GC after methanolysis or on-line coupled liquid chromatography-gas chromatography (LC-GC) [56]. The method of capillary GC followed by methanolysis could help reduce the total analysis time as it eliminates the need for saponification, extraction, and derivatization steps [54]. On-line coupling of LC-GC might offer rapid separation of free sterols in edible oils and fats since sample preparation can be integrated into the chromatographic procedure [57]. A detailed account of the developments in the analysis of sterols using on-line coupled LC-GC systems could be found elsewhere in the literature [58].

The possibility of detecting lard in ghee samples using cholesterol content as a marker was investigated [15]. As both cow and buffalo ghee samples had higher concentration of cholesterol in comparison to lard, decreasing trend in cholesterol content of admixtures was noticed with the increasing level of adulteration. This method enabled detection of lard as low as $5 \%$ in admixtures of both cow and buffalo gees. However, Alonso and co-workers [54] proposed an alternative procedure for direct analysis of sterols after methanolysis, which effectively eliminated the need for extraction of the saponifiable matter. This has been first tested to detect milk fat adulterations with palm oil, which is generally known to possess campesterol, stigmasterol, and $\beta$-sitosterol in higher proportions. As milk fat is usually found to contain higher concentration of cholesterol, a quantitative comparison between the chromatograms of the authentic sample and its admixtures would indicate either a reducing tendency in cholesterol or additional peaks appearing due to the presence of plant sterols originating from palm oil. Apart from showing a good repeatability, this method was claimed to be more rapid in comparison to other methods.

Analysis of hydrocarbons in plant and animal lipids has been the interest of researchers for many reasons. Determination of squalene, for instance, could be particularly useful for the detection of adulteration in olive oil, as it occurs in abundance in olive oil compared to any other vegetable oil [59]. The conventional methods of squalene analysis involve multi-steps, namely the isolation of the unsaponifiable matter, the fractionation of it into several sub-classes, and their subsequent analysis by GC. According to the European Union official methods [60], squalene can be determined simultaneously with waxes using a short capillary column coated with a low-polarity phase. Analysis of hydrocarbons in the unsaponifiable matter has also been useful to detect either 
lard or margarine in cow and buffalo ghees [15]. As lard was found to have a very high concentration of $n$-nonacosane in comparison to ghees of cow and buffalo, it could be used as parameter to detect adulterations in both cow and buffalo ghees at the minimum of $5 \%(\mathrm{w} / \mathrm{w})$. On the other hand, $n$-dotriacontane could be used as a marker to detect the presence of margarine in ghee since it did not occur as a minor constituent in ghee originated from either cow or buffalo milk. Inclusion of a set of hydrocarbons and sterols as standards as well as a check on the detection limit using proper statistical techniques were merits of this study.

Analysis of carotenoids could also be made use for authentication of oil and fats. Being a group of pigments in certain oils and fats, (all-E)- $\alpha$ - and (all-E)- $\beta$-carotene, (all$E)$-lutein, and (all-E)-zeaxanthin are reported as the most dominant constituents of this group. Analysis of carotenoids in lipids is usually carried out either by spectrophotometry or HPLC system using UV detector. Recently, Franke and coworkers [61] made a comparison between photometric and liquid chromatographic determinations of total carotenoid contents in selected seeds, their oils as well as the press cakes of them. In certain cases, carotenoid contents by photometric method were significantly higher than those obtained by HPLC method. Unlike the HPLC method, the calculation of carotenoid content by using photometric method is done according to absorbance maximum at $446 \mathrm{~nm}$ for the whole group of carotenoids though some of them might show slight differences in absorbance maxima. Hence, there could be a possibility for an over-estimation of total carotenoid content by photometric method. Apart from their significance as precursor in the biosynthesis of Vitamin A as well as protective agents against carcinogenesis, they are also useful as biomarkers to detect adulteration in some food lipids. Among the lipids originating from plants, palm oil is well-known to possess high concentration of carotenoids while coconut oil does not possess any of the carotenoids in significant amounts. Hence, the determination of $\beta$-carotene was found to be helpful to detect coconut oil adulteration with palm olein [62].

Tocopherols are yet another class of minor components used for quality assurance of oils and fats. Soybean, wheat germ, canola, peanut, and cottonseed oils are some of the richest sources of tocopherols, of which $\alpha, \beta, \gamma$, and $\delta$-tocopherols are the important constituents. Apart from being an oil with high amount of tocopherols, palm oil is used to have still another group of minor compounds known as tocotrienols. Analysis of tocopherols present in oils and fats could be easily done using HPLC system equipped with normal-phase column and a florescence detector [63]. However, HPLC systems equipped with reversed-phase column (RP-HPLC) and UV detection were also found to give good results [64]. According to some recent reports, RP-HPLC also has the advantage of faster chromatographic runs, faster equilibration time and better reproducibility of retention times [65]. In certain cases, better efficiency in separation was achieved through purification of oils using gel permeation chromatography as well as detection by evaporative light scattering detector (ELSD) [66]. The usefulness of tocopherol analysis has been demonstrated for detection of extra virgin olive oil (EVOO) with other seed oil [65], milk fat adulteration with vegetable fats [54, 67], sunflower oil with groundnut oil [17], and butter with margarine. For authentication of EVOO, calculation of the ratio of $a-/(b+c)$-tocopherol concentration by measuring tocopherols $(\mathrm{a}-,(\mathrm{b}+\mathrm{c})-$ and d-tocopherols) in EVOO and adulterated samples with RP-HPLC was found to be useful. According to some recent reports, the presence of palm mid fraction in $\mathrm{CB}$ as low as $5 \%(\mathrm{w} / \mathrm{w})$ could be monitored by using HPLC analysis of $\alpha$-tocotrienols $[68,69]$.

Authentication methods based on the composition of minor constituents of oils has to be applied cautiously as changes in the proportions of tocopherol and carotenoid contents could be possible due to bleaching and deodorization activities. While bleaching earth could adsorb part of the plant pigments, deodorization might cause thermal deterioration of them [61]. Apart from this, natural decomposition of tocopherols might also be possible during the storage due to the influence of light, oxygen, and temperature [63]. Hence, these factors should be taken into account while interpreting analytical results in authentication studies.

\section{Mid-infrared spectroscopic analyses}

In recent years, FTIR spectroscopy has emerged as a major analytical technique for a wide range of food analyses. It has become an attractive option because of its high speed in analysis and ease of operation. Considerable efforts have been made so far to use this technique to detect adulterations in oils and fats. In the early nineteen nineties, FTIR spectroscopy has been employed to characterize of pure vegetable oils $[70,71]$, butters fat, and margarines [72] to distinguish between plant oils and lard [71] as well as lard and other animal fats [73]. All these studies concluded that the mid-IR spectra of most oils and fats were apparently similar despite some dissimilarities in spectral features of certain regions. The observed differences in spectral characteristics were due to molecular compositional and structural differences such as degree of unsaturation and chain length, monounsaturated to polyunsaturated acyl group ratio, variations in trans fatty acid content among the oils [7072]. These differences were subsequently exploited to check adulteration practices in oils and fats [74]. A summary of the several studies reported on the detection of adulteration in vegetable oils, namely canola oil, corn oil, cod-liver oil, extra virgin olive oil, soybean oil, and sunflower oil has been given in Table 2.

Depending on the nature of the adulteration, various approaches have been used by researchers [Table 2]. For detection of lard adulteration in beef fat, goat fat, and chicken fat, spectral changes in four frequency regions have been considered: (A): 3009-3000, (B): 1418-1417, (C): 1116-1098 and (D): $968-966 \mathrm{~cm}^{-1}$. In this case, the variations in the spectral properties have been exploited to develop predictive models for quantification of lard by using simple regression [73]. As the mid-IR spectra of majority of oils and fats are apparently similar, several researchers employed chemo metric techniques such as discriminant analysis to exploit subtle differences in the spectra. This approach has been successfully applied to helped differentiate extra virgin olive oil from other seed oils [5], pork from other meat species [10], cocoa butter from cocoa butter mixed with other vegetable fats [75], cod- 


\begin{tabular}{|c|c|c|c|c|c|}
\hline Product & Objective & Method & Wavenumber & Main results & Ref. no. \\
\hline $\begin{array}{l}\text { Meat lipids of } \\
\text { fresh meat species and } \\
\text { canned meat products }\end{array}$ & $\begin{array}{l}\text { To differentiate meat lipids of } \\
\text { different animal species }\end{array}$ & $\begin{array}{l}\text { FITR spectroscopy with ATR } \\
\text { element and PCA analysis }\end{array}$ & $1800-1000 \mathrm{~cm}^{-1}$ & $\begin{array}{l}\text { PCA application for FTIR data } \\
\text { helped to distinguish pork from } \\
\text { chicken and turkey }\end{array}$ & {$[10]$} \\
\hline $\begin{array}{l}\text { Fresh Animal body fats } \\
\text { (Lamb, cow, and chicken) }\end{array}$ & $\begin{array}{l}\text { To differentiate meat lipids of } \\
\text { different animal species }\end{array}$ & $\begin{array}{l}\text { FITR spectroscopy with simple } \\
\text { regression analysis }\end{array}$ & $\begin{array}{l}3008-3000,1418-1417 \\
1385-1370,1126-1085 \\
968-965 \mathrm{~cm}^{-1}\end{array}$ & $\begin{array}{l}\text { Able to differentiate lard from meat lipids } \\
\text { of different animal species. Regression } \\
\text { models were useful to quantify lard } \\
\text { contamination in these lipids }\end{array}$ & {$[73]$} \\
\hline $\begin{array}{l}\text { Fresh Animal body fats } \\
\text { (Lamb, cow, and chicken) }\end{array}$ & $\begin{array}{l}\text { To differentiate meat lipids of } \\
\text { different animal species }\end{array}$ & $\begin{array}{l}\text { FITR spectroscopy with deuterat- } \\
\text { ed triglycine sulfate detector and } \\
\text { PLS regression analysis }\end{array}$ & $\begin{array}{l}3010-2000,1220- \\
1095,968-965 \mathrm{~cm}^{-1}\end{array}$ & $\begin{array}{l}\text { PLS models were useful to quantify } \\
\text { lard contamination in these lipids }\end{array}$ & {$[78]$} \\
\hline $\begin{array}{l}\text { Fresh Animal body fats } \\
\text { (Lamb, cow, and chicken) }\end{array}$ & $\begin{array}{l}\text { To quantify the proportion of } \\
\text { lard contamination in meat lipids }\end{array}$ & $\begin{array}{l}\text { FITR spectroscopy with PLS } \\
\text { regression and discriminant analysis }\end{array}$ & $\begin{array}{l}3300-700,1,500-900 \\
\mathrm{~cm}^{-1}\end{array}$ & $\begin{array}{l}\text { PLS models were useful to quantify } \\
\text { lard contamination in these lipids }\end{array}$ & {$[77]$} \\
\hline Cake lipids & $\begin{array}{l}\text { To quantify the proportion of } \\
\text { lard contamination in cake lipids }\end{array}$ & $\begin{array}{l}\text { FITR spectroscopy with ATR } \\
\text { element and PLS regression analysis }\end{array}$ & $\begin{array}{l}1117-1097,990-950 \\
\mathrm{~cm}^{-1}\end{array}$ & $\begin{array}{l}\text { PLS models for quantification of lard } \\
\text { with a minimum detection of } 4 \%(\mathrm{w} / \mathrm{w})\end{array}$ & {$[83]$} \\
\hline $\begin{array}{l}\text { Chocolate and its } \\
\text { products }\end{array}$ & $\begin{array}{l}\text { To quantify the proportion of lard } \\
\text { contamination in chocolate lipids }\end{array}$ & $\begin{array}{l}\text { FITR spectroscopy with ATR } \\
\text { element and PLS regression analysis }\end{array}$ & $4000-650 \mathrm{~cm}^{-1}$ & $\begin{array}{l}\text { PLS models for quantification of lard } \\
\text { with a minimum detection of } 3 \%(w / w)\end{array}$ & {$[84]$} \\
\hline Cod liver oil & $\begin{array}{l}\text { To quantify the proportion of lard } \\
\text { contamination in cod liver oil }\end{array}$ & $\begin{array}{l}\text { FITR spectroscopy with ATR and } \\
\text { PLS regression analysis }\end{array}$ & $1035-1030 \mathrm{~cm}^{-1}$ & $\begin{array}{l}\text { PLS models for quantification of lard } \\
\text { with a minimum detection of } 1 \%(\mathrm{v} / \mathrm{v})\end{array}$ & {$[76]$} \\
\hline $\begin{array}{l}\text { Some vegetable oils } \\
\text { (Canola oil, corn oil, } \\
\text { extra virgin olive oil) }\end{array}$ & $\begin{array}{l}\text { To quantify the proportion } \\
\text { of lard contamination in the } \\
\text { vegetable oils }\end{array}$ & $\begin{array}{l}\text { FITR spectroscopy with ATR and } \\
\text { PLS, PCR, and DA }\end{array}$ & $1500-1000 \mathrm{~cm}^{-1}$ & $\begin{array}{l}\text { PLS models for quantification of lard } \\
\text { with a minimum detection of } 1 \%(\mathrm{v} / \mathrm{v})\end{array}$ & {$[79]$} \\
\hline Extra virgin olive oil & $\begin{array}{l}\text { To quantify the proportion of } \\
\text { refined olive oil and walnut oil } \\
\text { in extra virgin olive oil }\end{array}$ & $\begin{array}{l}\text { FITR spectroscopy with ATR and } \\
\text { PLS regression }\end{array}$ & $\begin{array}{l}3100-2800,1800- \\
1000 \mathrm{~cm}^{-1}\end{array}$ & $\begin{array}{l}\text { PLS models for quantification of } \\
\text { walnut oil in extra virgin olive oil with } \\
\text { a minimum detection of } 5 \%(\mathrm{v} / \mathrm{v})\end{array}$ & {$[82]$} \\
\hline Biscuit lipids & $\begin{array}{l}\text { To quantify the proportion of } \\
\text { lard contamination }\end{array}$ & $\begin{array}{l}\text { FITR spectroscopy with ATR } \\
\text { element and PLS-DA regression } \\
\text { analysis }\end{array}$ & $\begin{array}{l}3050-2800,1800- \\
1600,1500-650 \mathrm{~cm}^{-1}\end{array}$ & $\begin{array}{l}\text { Cooman plot showed that vegetable } \\
\text { fats/oils and animal fats were } \\
\text { clustered into distinct groups }\end{array}$ & {$[85]$} \\
\hline Cocoa butter & $\begin{array}{l}\text { To differentiate cocoa butter and } \\
\text { cocoa butter equivalents }\end{array}$ & $\begin{array}{l}\text { FITR spectroscopy with principle } \\
\text { component analysis }\end{array}$ & $4000-600 \mathrm{~cm}^{-1}$ & $\begin{array}{l}\text { Application of principle component } \\
\text { analysis was able to distinguish between } \\
\text { cocoa butter and cocoa butter equivalents }\end{array}$ & {$[75]$} \\
\hline Red fruit oil & $\begin{array}{l}\text { To quantify the proportion of } \\
\text { either corn oil or soybean oil } \\
\text { contamination }\end{array}$ & $\begin{array}{l}\text { FITR spectroscopy with ATR ele- } \\
\text { ment and PLS regression analysis }\end{array}$ & $4000-600 \mathrm{~cm}^{-1}$ & $\begin{array}{l}\text { PLS models for quantification of either } \\
\text { corn oil or soybean oil in red fruit oil }\end{array}$ & {$[81]$} \\
\hline Extra virgin olive oil & $\begin{array}{l}\text { To differentiate extra virgin olive } \\
\text { oil from adulterated samples } \\
\text { and quantify the proportion of } \\
\text { adulterant }\end{array}$ & $\begin{array}{l}\text { FITR spectroscopy with ATR } \\
\text { element and PCR and PLS regres- } \\
\text { sion analysis }\end{array}$ & $\begin{array}{l}3007,2922,2853 \\
1754,1160,1117 \mathrm{~cm}^{-1}\end{array}$ & $\begin{array}{l}\text { Able to differentiate between pure EVOO } \\
\text { and EVOO adulterated with } 5 \% \mathrm{~V} / \mathrm{V}\end{array}$ & {$[74]$} \\
\hline Fish packing oils & $\begin{array}{l}\text { To differentiate extra virgin olive } \\
\text { oil from high-oleic sunflower oil }\end{array}$ & $\begin{array}{l}\text { FITR spectroscopy with ATR } \\
\text { element and PLS-DA regression } \\
\text { analysis }\end{array}$ & $3030-2800 \mathrm{~cm}^{-1}$ & $\begin{array}{l}\text { Able to discriminate olive oil from } \\
\text { high oleic-sunflower oil }\end{array}$ & {$[80]$} \\
\hline
\end{tabular}

liver oil from cod-liver oil mixed with lard [76], and lard from lard mixed with beef fat, goat fat, and chicken fat $[77,78]$. According to the overall findings of these studies, the finger print region (1500-1000 $\mathrm{cm}^{-1}$ ) would be most appropriate to be used in discriminant analysis methodology to differentiate pure oils from their admixtures containing lard or any other plant oil [79]. However, some other studies differed from this view point as they made use of the dissimilarities in the spectral bands of other regions of the spectrum. Vasconcelos and coworkers [74] showed that $3007,2922,2853,1754,1160$, and $1117 \mathrm{~cm}^{-1}$ were best suited to differentiate extra virgin olive oil from those adulterated peanut oil while Dominguez-vidal and co-workers [80] indicated that the strongest contribution to differentiate extra virgin olive oil from high-oleic sunflower oil came from 3010, 2920, and $2852 \mathrm{~cm}^{-1}$. Rohman and coworkers [81] used the entire frequency region (4000-600 $\mathrm{cm}^{-1}$ ) to deal with adulteration of red fruit oil with corn and soybean oil mixture.
For estimation of the proportion of adulterant quantitatively, application of partial least square (PLS) methodology was considered in majority of the cases to select the most suitable spectral regions showing best correlations between FTIR spectra and the concentration of the analyte(s) of interest [82]. However, some other researchers pointed out that application of PLS regression was required for the entire finger print region (1500-900 $\left.\mathrm{cm}^{-1}\right)$ for the quantification of the adulterant $[77,78,81]$. They insisted that same approach was still required to determine lard adulteration level in lipids extracted from product such as cake [83], chocolate [84], biscuits [85], etc. At times, semi-quantitative approaches were proposed to estimate lard content in the lipids extracted from these products since steady changes in absorbance values were noticed in different regions of the spectra with the increasing proportion of lard. For instance, increasing lard content in cake formulation caused a decreased in absorbance values of spectral peaks in the frequency region of $990-950 \mathrm{~cm}^{-1}$. This could be probably due to the fact that shortening used in the cake 
formulation had high trans fatty acid content [83]. However, this particular frequency region has not been found to be useful for lard detection in chocolate as genuine cocoa butter was not found to possess any trans fatty acid content [84]. Because of this reason, the PLS calibration model to quantify lard content in chocolate was developed on the basis of spectral data in the entire frequency region $4000-650 \mathrm{~cm}^{-1}$. These findings clearly showed a common region could not be used to run the PLS regression for quantification of lard content in lipids extracted from different food products. Instead, spectral regions suitable for quantification of adulterant needs to be selected based on the differences in sample matrix.

\section{Future Prospects}

In the recent literature, there are several reports on the use of modern techniques such as FT-NIR spectroscopy $[86,87],{ }^{1} \mathrm{H}$ and ${ }^{13} \mathrm{C}$ nuclear magnetic resonance (NMR) spectroscopy [88], FT-Raman spectroscopy [89], isotope ratio mass spectrometry [90] for the detection of various food adulteration practices. FT-NIR spectroscopy, for instance, has already been recognized for its uses in the measurement of adulterations in milk fat [86], olive oil [87], etc. Likewise, the potential applications of FT-Raman spectroscopy in detection of virgin olive oil adulterations by pomace, soybean, and corn oils have also been highlighted [89]. As ${ }^{13} \mathrm{C}$ NMR has been recognized as a valuable tool for analysis of the most abundant fatty acids of various oils, there has been a growing interest among researchers to use it to detect adulterations of virgin olive oil [88]. However, the literature on the use of these modern analytical techniques for detection of animal fats in food systems, plant fats in cocoa butter or milk fat is limited. Hence, there is much scope to expand the investigations on lipid adulterations in new directions.

\section{Concluding Remarks}

This review highlighted the developments on the use of analytical techniques such as GLC, HPLC, and FTIR spectroscopy to control adulteration practices in food lipids. As the nature of the FA and TAG compositions of lipids and their adulterants vary drastically, devising generalized criteria for purity determination is a challenging task. However, establishment of comprehensive data bases giving acceptable ranges of FA and TAGs of individual lipids prone to adulteration would be essential for regulatory purposes. There is an increasing trend to use chemo metrics techniques to analyze the FA and TAG compositional data either for differentiating genuine products from adulterated ones or for estimation of the level of adulteration. Chromatographic techniques have also given several successes to detect adulterations in food lipids by monitoring cholesterol and phytosterols as biomarkers. When compared to chromatographic techniques, Mid-IR spectroscopy is an attractive option for detection of adulterations in oils and fats due to the speed of analysis, and minimal sample preparation. Since adulteration in oils and fats could bring about deviations in different spectral regions of vegetable oils, discriminant analysis methodology could be able to differentiate adulterated ones from real samples. For this purpose, selecting the finger print region of the spectra has yielded considerable success in majority of the cases. For quantitative estimation of the adulteration, PLS based calibration models have been considered in majority of the cases. However, a PLS model developed for a particular oil might not be applicable to some other oils. Hence, there is a need to develop PLS models for individual food system using different spectral regions.

\section{References}

1. Manning L, Soon JM. 2014. Developing systems to control food adulteration. Food Policy 49(1): 23-32. doi: 10.1016/j. foodpol.2014.06.005

2. Kamal M, Karoui R. 2015. Analytical methods coupled with chemometric tools for determining the authenticity and detecting the adulteration of dairy products: A review. Trend Food Sci Technol 46(1): 27-48. doi: 10.1016/j.tifs.2015.07.007

3. Rossell JB, King B, Downes MJ. 1985. Composition of oils. J Am Oil Chem Soc 62(2): 221-230. doi: 10.1007/BF02541382

4. Rossell JB, King B, Downes MJ. 1983. Detection of adulteration. J Am Oil Chem Soc 60(2): 333-339. doi: 10.1007/BF02543513

5. Lai YW, Kemsley EK, Wilson RH. 1994. Potential of fourier transform infrared spectroscopy for the authentication of vegetable oils. J Agric Food Chem 42(5): 1154 -1159. doi: 10.1021/jf00041a020

6. Firestone D, Summers JL, Reina RJ, Adams WS. 1985. Detection of adulterated and misbranded olive oil products. $\mathrm{J} \mathrm{Am} \mathrm{Oil} \mathrm{Chem} \mathrm{Soc}$ 62(11): 1558-1562. doi: 10.1007/BF02541684

7. Dourtoglou VG, Dourtoglou T, Antonopoulos A, Stefanou E, Lalas S, et al.2003. Detection of olive oil adulteration using principal component analysis applied on total and regio FA content. J Am Oil Chem Soc 80(3): 203-208. doi: 10.1007/s11746-003-0677-1

8. Marikkar JMN, Lai OM. 2004. Detection of adulteration in lauric oils: use of different analytical techniques. In: Peiris TSG and Ranasinghe CS (eds) Proceedings II, 270-284: International Conference of the Coconut Research Institute of Sri Lanka, Lunuwila, Sri Lanka.

9. Sosa JFM, Pesini ER, Montoya J, Roncales P, Perez MJL, et al. 2000. Direct and highly species-specific detection of pork meat and fat in meat products by PCR amplification of mitochondrial DNA. J Agric Food Chem 48(7): 2829-2832. doi: 10.1021/jf9907438

10. Jowder OA, Kemsley EK, Wilson RH.1997.Mid-infrared spectroscopy and authenticity problems in selected meats: a feasibility study. Food Chem 59(2): 195-201. doi: 10.1016/S0308-8146(96)00289-0

11. Saeed T, Ali SG, Rahman HA, Saway WN. 1989. Detection of pork and lard as adulterants in processed meat: liquid chromatographic analysis of derivatized triglycerides. J Ass Offi Anal Chem 72(6): 921-925.

12. Saeed T, Abu-Dagga F, Rahman HA. 1986. Detection of pork and lard as adulterants in beef and mutton mixtures.J Ass Offi Anal Chem 69: 999-1002.

13. Marikkar JMN, Lai OM, Ghazali HM, Che Man YB. 2001. Detection of lard and randomized lard as adulterants in RBD palm oil by differential scanning calorimetry. J Am Oil Chem Soc 78(11): 1113-1119. doi: $10.1007 / \mathrm{s} 11746-001-0398-5$

14. Seriburi V,Akoh CC.1998. Enzymatic interesterification of lard and higholeic sunflower oil with candida anatartica lipase to produce plastic fats. $J$ Am Oil Chem Soc 75(10): 1339-1345. doi: 10.1007/s11746-998-0181-x

15. Farag RS, Ahmed FA, Shihata AA, Aboraya SH, Abdalla AF. 1982. Use of unsaponifiable matter for detection of ghee adulteration with other fats. J Am Oil Chem Soc 59(12): 557-560. doi: 10.1007/BF02636323

16. Lambelet P, Ganguli NC. 1983. Detection of pig and buffalo body fat in cow and buffalo ghees by differential scanning calorimetry. $\mathrm{J} \mathrm{Am} \mathrm{Oil}$ Chem Soc 60(5): 1005-1008. doi: 10.1007/BF02660216

17. Rossell JB. 1998. Development of purity criteria for edible vegetable oils. In: Hamilton RJ (ed) Blackie Academic and Professional, London, UK, pp 265-289.

18. Azadmard-Damirchi S. 2010. Review of the use of phytosterols as a 
detection tool for adulteration of olive oils with hazelnut oil. Food Add and Contam 27(1): 1-10. doi: 10.1080/02652030903225773

19. Li-Chan E. 1994. Developments in the detection of adulteration of olive oil. Trends Food Sci Technol 5(1): 3-11. doi: 10.1016/09242244(94)90042-6

20. Reid LM, O’Donnell CP, Downey G. 2006. Recent technological advances for the determination of food authenticity. Trends Food Sci Technol 17(7): 344-353. doi: 10.1016/j.tifs.2006.01.006

21. Raihana AR, Marikkar JMN, Ismail A, Musthafa S. 2015. A review on food values of selected fruits' seeds. Int J Food Prop 18(11): 2380-2392. doi: 10.1080/10942912.2014.980946

22. Ulberth F.1994. Detection of milk fat adulteration by linear discriminant analysis of fatty acid data. J AOAC Int 77(5): 1326-1334.

23. Norris FA. 1982. Analytical methods. In: Swern D (ed) Bailey's Industrial Oil and Fat Products, John Wiley and Sons, Inc., New York, USA, pp 407-525.

24. Firestone D. 1988. General referee reports: oils and fats. J Ass Offi Anal Chem 71: 76-78.

25. Marikkar JMN, Ghazali HM, Che Man YB, Peiris TSG, Lai OM. 2005. Use of gas chromatography in combination with pancreatic lipolysis and multivariate data analysis techniques for identification of lard contamination in some vegetable oils. Food Chem 90(1-2): 23-30. doi: 10.1016/j.foodchem.2004.03.021

26. Firestone D, Carson KL, Reina RJ. 1988. Update on control of olive oil adulteration and misbranding in the United States. J Am Oil Chem Soc 65(5): 788-792. doi: 10.1007/BF02542533

27. Farag RS, Aboraya SH, Ahmed FA, Hewedi FM, Khalifa HH. 1983. Fractional crystallization and gas chromatographic analysis of fatty acids as a means of detecting butter fat adulteration. $\mathrm{J} \mathrm{Am} \mathrm{Oil} \mathrm{Chem} \mathrm{Soc}$ 60(9): 1665-1669. doi: 10.1007/BF02662429

28. Gamazo-Vazquez J, Garcia-Falco MS, Simal-Gandara J. 2003. Control of olive oil contamination by sunflower seed oil by GC-MS of fatty acid methyl esters. Food Control 14(7): 463-467. doi: 10.1016/S09567135(02)00102-0

29. Seo HY, Ha J, Shin DB, Shim SL, No KM, et al. 2010. Detection of corn oil in adulterated sesame oil by chromatography and carbon isotope analysis. J Am Oil Chem Soc 87(6): 621-626. doi: 10.1007/ s11746-010-1545-6

30. Marikkar JMN, Ghazali HM, Long K, Lai OM. 2003. Lard uptake and its detection in selected food products deep-fried in lard. Food Res Int 36(9-10): 1047-1060. doi: 10.1016/j.foodres.2003.08.003

31. Chacko GK, Perkins EG. 1965. Anatomical variation in fatty acid composition and triglyceride distribution in animal depot fats. $\mathrm{Jm} \mathrm{Oil}$ Chem Soc 42(12): 1121-1124. doi: 10.1007/BF02636926

32. Huang Z,Wang B, Crenshaw AA.2006. A simple method for the analysis of trans fatty acid with GC-MS and ATe-Silar-90 capillary column. Food Chem 98(4): 593-598. doi: 10.1016/j.foodchem.2005.05.013

33. Philips JB, Beens J. 1999. Comprehensive two-dimensional gas chromatography: a hyphenated method with strong coupling between the two dimensions.J Chrom A 856(1-2): 331-347. doi: 10.1016/S00219673(99)00815-8

34. Indrasti D, Che Man YB, Mustafa S, Hashim DM. 2010. Lard detection based on fatty acids profiles using comprehensive gas chromatography hyphenated with time-of-flight mass spectrometry. Food Chem 122(4): 1273-1277. doi: 10.1016/j.foodchem.2010.03.082

35. Chin ST, Che Man YB, Tan CP, Hashim DM. 2009. Rapid profiling of animal-derived fatty acids sing fats GC X GC coupled to time-of-flight mass spectrometry. J Am Oil Chem Soc 86(10): 949-958. doi: 10.1007/ s11746-009-1427-y

36. Marikkar JMN, Ghazali HM, Che Man YB, Peiris TSG, Lai OM. 2005. Distinguishing lard from other animal fats in admixtures of some vegetable oils using liquid chromatographic data coupled with multivariate data analysis. Food Chem 91(1): 5-14. doi: 10.1016/j. foodchem.2004.01.080
37. Timms RE. 1980. Detection and quantification of non-milk fat in mixtures of milk and non-milk fats. J Dairy Res 47(3): 295-303. doi: 10.1017/S002202990002118X

38. Padley FB, Timme RE. 1980. The determination of cocoa butter equivalents in chocolate. J Am Oil Chem Soc 57(9): 286-293. doi: 10.1007/BF02662209

39. Rashood KA, Shaaban RRA,Moety EMA, RaufA.1996. Compositional and thermal characterization of genuine and randomized lard: A comparative study. J Am Oil Chem Soc 73(3): 303-309. doi: 10.1007/ BF02523423

40. Parodi PW. 1973. Detection of synthetic and adulterated butterfat 4 . GLC triglyceride analysis. Aus J Dairy Technol 28(1): 38-42.

41. Fontecha J, Diaz V, Fraga MJ, Juarez M. 1998. Triglyceride analysis by gas chromatography in assessment of authenticity of goat milk fat. $J$ Am Oil Chem Soc 75(12): 1893-1896. doi: 10.1007/s11746-998-0347-6

42. Goudjil H, Fontecha J, Fraga MJ, Juarez M. 2003. TAG composition of Eve's milk fat. Detection of foreign fats. J Am Oil Chem Soc 80(3): 219222. doi: $10.1007 / \mathrm{s} 11746-003-0680-6$

43. Simoneau C,Hannaert P,Anklam E. 1999. Detection and quantification of cocoa butter equivalents in chocolate model system: analysis of triglyceride profiles by high resolution GC. Food Chem 65(1): 111-116. doi: 10.1016/S0308-8146(98)00106-X

44. Lipp M, Anklam E. 1998. Review of cocoa butter and alternative fats for use in chocolate - Part B. analytical approaches for identification and determination. Food Chem 62(1): 99-108. doi: 10.1016/S03088146(97)00161-1

45. Kapoulas VM, Andrikopoulos NK. 1986. Detection of olive oil adulteration with linoleic acid-rich oils by reversed-phase highperformance liquid chromatography J Chromatogra A 366: 311-320. doi: 10.1016/S0021-9673(01)93478-8

46. Antoniosi NR, Carrilho E, Lancas FM. 1993. Fast quantitative analysis of soybean oil in olive oil by high-temperature capillary gas chromatography. J Am Oil Chem Soc 70(10): 1051-1053. doi: 10.1007/ BF02543037

47. Salivaras E, McCurdy AR. 1992. Detection of olive oil adulteration with canola oil from triacylglycerol analysis by reversed-phase highperformance liquid chromatography. J Am Oil Chem Soc 69(9): 935938. doi: 10.1007/BF02636347

48. Tsimidou M, Macrae R, Wilson I. 1987. Authentication of virgin olive oils using principal component analysis of triglyceride and fatty acid profiles: part 2-detection of adulteration with other vegetable oils. Food Chem 25(4): 251-258. doi: 10.1016/0308-8146(87)90011-2

49. Flor RV, Hecking LT, Martin BD. 1993. Development of highperformance liquid chromatography criteria for determination of grades of commercial olive oils. Part I. the normal ranges for the triacylglycerols. J Am Oil Chem Soc 70(2): 199-203. doi: 10.1007/BF02542626

50. Cert W, Moreda MC, Pe'rez-Camino A. 2000. Chromatographic analysis of minor constituents in vegetable oils. J Chromatogr A 881(12): 131-148. doi: 10.1016/S0021-9673(00)00389-7

51. Bragagnolo N, Rodriguez-Amaya, DB. 2002. Simultaneous determination of total lipid, cholesterol and fatty acids in meat and back fat of suckling and adult pigs. Food Chem 79(2): 255 -260. doi: 10.1016/ S0308-8146(02)00136-X

52. Boskou D. 2008. Phenolic compounds in olives and olive oil. In: Boskou D (ed) Olive Oil: Minor Constituents and Health. CRC Press, Florida, USA, pp 11-45.

53. Castillo MLRD, Caja MDM, Herraiz M, Gracia P. 1998. Blanch. Rapid recognition of olive oil adulterated with hazelnut oil by direct analysis of the enantiomeric composition of filbertone. J Agric Food Chem 46(12): 5128-5131. doi: 10.1021/jf9807014

54. Alonso L, Fontecha J, Lozada L, Juarez M. 1997. Determination of mixtures in vegetable oils and milk fat by analysis of sterol fraction by gas chromatography. J Am Oil Chem Soc 74(2): 131-135. doi: 10.1007/ s11746-997-0157-2 
55. Al-Ismail KM, Alsaed AK, Ahmad R, Al-Dabbas M. 2010. Detection of olive oil adulteration with some plant oils by GLC analysis of sterols using polar column. Food Chem 121(4): 1255-1259. doi: 10.1016/j. foodchem.2010.01.016

56. Plank C, Lorbeer E. 1993. Analysis of free and esterified sterols in vegetable oil methyl esters by capillary GC. J High Resol Chromatogr 16(8): 483-487. doi: 10.1002/jhrc.1240160808

57. Senorans FJ, Tabera J, Herraiz M. 1996. Rapid separation of free sterols in edible oils by on-line coupled reversed phase liquid chromatographygas chromatography. J Agric Food Chem 44(10): 3189-3192. doi: 10.1021/jf960071a

58. Villen J, Blanch GP, Castillo MLR, Herraiz M. 1998. Rapid and simultaneous analysis of free sterols, tocopherols, and squalene in edible oils by coupled reversed-phase liquid chromatography-gas chromatography. J Agri Food Chem 46(4): 1419-1422. doi: 10.1021/ jf9707061

59. Nenadis N, Tsimidou M. 2002. Determination of squalene in olive oil using fractional crystallization for sample preparation. $\mathrm{J} \mathrm{Am} \mathrm{Oil} \mathrm{Chem}$ Soc 79(3): 257-259. doi: 10.1007/s11746-002-0470-1

60. European Union Commission 1993. Regulation EEC/183/ 93, Off J Eu Comm, L248.

61. Franke S, Frohlich K, Werner S, Bohm V, Schone F. 2010. Analysis of carotinoids and vitamin $\mathrm{E}$ in selected oil seeds, press cakes and oils. Eu J Lipid Sci Technol 112(10): 1122-1129. doi: 10.1002/ejlt.200900251

62. Viver MJ.1999. A simple method for detection of palm olein in coconut oil. Indian Coco J11: 6-7.

63. Coors U, Montag A. 1988. Untersuchungen zur Stabilität des Tocopherolgehaltes pflanzlicher Öle. Fett/Lipid 90(4): 129-136. doi: 10.1002/lipi.19880900402.

64. Andrikopoulos NK, Brueschweilet H, Felber H, Taeschler CH. 1991. HPLC analysis of phenolic antioxidants, tocopherols, and triglycerides. $J$ Am Oil Chem Soc 68(6): 359-364. doi: 10.1007/BF02663750

65. Huilun C, Marco A, Carlo F, Elpidio T, Giuseppe S, et al. 2011. Tocopherol speciation as first screening for the assessment of extra virgin olive oil quality by reversed-phase high-performance liquid chromatography/fluorescence detector. Food Chem 125(4): 1423-1429. doi: 10.1016/j.foodchem.2010.10.026

66. Chase GW Jr., Akoh CC, Eitenmiller RR. 1994. Analysis of tocopherols in vegetable oils by high-performance liquid chromatography: comparison of fluorescence and evaporative light-scattering detection. $J$ Am Oil Chem Soc 71(8): 877-880. doi: 10.1007/BF02540466

67. Keeney M, Bachman KC, Tikriti HH, King RL. 1971. Rapid vitamin E method for detecting adulteration of dairy products with non-coconut vegetable oils. J Dairy Sci 54(11): 1702-1703. doi: 10.3168/jds. S00220302(71)86092-7

68. Elham MF, Jinap S, Che Man YB, Noraini I. 2008. Application of alpha-tocotrienol for detection of palm mid-fraction in dark chocolate formulation. Eu Food Res Technol 228(2): 163-168. doi: 10.1007/ s00217-008-0919-6

69. Elham MF, Jinap S, Che Man YB, Noraini I. 2008. Detection and quantification of palm mid fraction in chocolate model system. Int J Food Sci Technol 43(6): 1083-1087. doi: 10.1111/j.1365-2621.2007. 01570.x

70. Guillen MD, Ruiz A, Cabo N, Chirinos R, Pascual G. 2003. Characterization of sacha inchi (Plukenetia volubilis L.) oil by FTIR spectroscopy and ${ }^{1} \mathrm{H}$ NMR. Comparison with line seed oil. J Am Oil Chem Soc 80(8): 755-762. doi: 10.1007/s11746-003-0768-z

71. Guillen MD, Cabo N. 1997. Characterization of edible oils and lard by fourier transform infrared spectroscopy. Relationships between composition and frequency of concrete bands in the fingerprint region. $J$ Am Oil Chem Soc 74(10): 1281-1286. doi: 10.1007/s11746-997-0058-4

72. Safar M, Bertrand D, Robert P, Devaux, MF, Genot C. 1994. Characterization of edible oils, butters and margarines by fourier transform infrared spectroscopy with attenuated total reflectance. $\mathrm{JAm}$

\section{Oil Chem Soc 71(4): 371-377. doi: 10.1007/BF02540516}

73. Che Man YB, Mirgani MES. 2001. Detection of lard mixed with body fats of chicken, lamb, and cow by FTIR spectroscopy. J Am Oil Chem Soc 78(7): 753-761. doi: 10.1007/s11746-001-0338-4

74. Vasconcelos M, Coelho L, Barros A, Martins de Almeida JMM. 2015. Study of adulteration of extra virgin olive oil with peanut oil using FTIR spectroscopy and chemometrics. Cogent Food Agric 1: 1-13. doi: 10.1080/23311932.2015.1018695

75. Goodacre R, Anklam E. 2001. Fourier transform infrared spectroscopy and chemometrics as a tool for rapid detection of other vegetable fats mixed in cocoa butter. J Am Oil Chem Soc 78(10): 993-1000. doi: $10.1007 / \mathrm{s} 11746-001-0377-\mathrm{x}$

76. Rohman A, Che Man YB. 2009. Analysis of cod-liver oil adulteration using fourier transform infrared (FTIR) spectroscopy. $\mathrm{J} \mathrm{Am} \mathrm{Oil} \mathrm{Chem}$ Soc 86: 1149-1153. doi: 10.1007/s11746-009-1453-9

77. Rohman A, Che Man YB. 2010. FTIR spectroscopy combined with chemometrics for analysis of lard in the mixtures with body fats of lamb, cow, and chicken. Int Food Res J 17: 519-526.

78. Jaswir I, Mirghani MES, Hassan TH, Said MZM. 2003. Determination of lard in mixture of body fats of mutton and cow by fourier transform infrared spectroscopy. J Oleo Sci 52(12): 633-638. doi: 10.5650/ jos.52.633

79. Rohman A, Che Man YB, Ismail A, Puziah H.2011. FTIR spectroscopy combined with chemometrics for analysis of lard in some vegetable oils. Cyta-J Food 9(2): 96-101. doi: 10.1080/19476331003774639

80. Dominguez-vidal A, Rosa JP, Cuadros-Rodriguez LC, Canda MJA. 2016. Authentication of canned fish packing oils by means of Fourier transform infrared spectroscopy. Food Chem 190: 122-127. doi: 10.1016/j.foodchem.2015.05.064

81. Rohman A, Setyaningrum DL, Riyanto S 2014. FTIR spectroscopy combined with partial least square for analysis of red fruit oil in ternary mixture system. Intl J Spectr 2014: 785914. doi: 10.1155/2014/785914

82. Lai YW, Kemsley EK, Wilson RH. 1995. Quantitative Analysis of potential adulterants of extra virgin olive oil using infrared spectroscopy. Food Chem 53(1): 95-98. doi: 10.1016/0308-8146(95)95793-6

83. Che Man YB, Syariza ZA, Mirghani MES, Jinap S, Bakar J. 2005. Detection of lard adulteration in cake formulation by Fourier transform infrared (FTIR) spectroscopy. Food Chem 92(2): 365-371. doi: 10.1016/j.foodchem.2004.10.039

84. Che Man YB, Syariza ZA, Mirghani MES, Jinap S, Bakar J. 2005. Analysis of potential lard adulteration in chocolate and chocolate products using fourier transform infrared spectroscopy. Food Chem 90(4): 815-819. doi: 10.1016/j.foodchem.2004.05.029

85. Che Man YB, Syahariza ZA, Rohman A. 2011. Discriminant analysis of selected edible fats and oils and those in biscuit formulation using (FTIR) spectroscopy. Food Anal Meth 4(3): 404-409. doi: 10.1007/ s12161-010-9184-y

86. Sato T, Kawano S, Iwamoto M. 1990. Detection of foreign fat adulteration of milk by near infrared spectroscopic method.J Dairy Sci 73(12): 3408-3413. doi: 10.3168/jds. S0022-0302(90)79037-6

87. Wesley IJ, Barnes RJ, McGill AEJ. 1995. Measurement of adulteration of olive oils by near-infrared spectroscopy. J Am Oil Chem Soc 72(3): 289-292. doi: 10.1007/BF02541084

88. Mavromoustakos T, Zervou M, Bonas G, Kolocouris A, Petrakis P. 2000. A novel analytical method to detect adulteration of virgin olive oil by other oils. J Am Oil Chem Soc 77(4): 405-411. doi: 10.1007/s11746000-0065-x

89. Baeten V, Meurens M, Morales MT, Aparicio R. 1996. Detection of virgin olive oil adulteration by fourier transform Raman spectroscopy. $J$ Agric Food Chem 44(8): 2225-2230. doi: 10.1021/jf9600115

90. Nina Naqiyah AN, MarikkarJMN, Dzulkifly MH.2013. Differentiation of lard, chicken fat, beef fat, and mutton fat by GCMS and EA-IRMS techniques. J Oleo Sci 63(7): 459-464. doi: 10.5650/jos.62.459 